Pak. j. sci. ind. res. Ser. A: phys. sci. 2017 60(1) 1-8

\title{
Turmeric Powder as a Natural Heavy Metal Chelating Agent: Surface Characterisation
}

\author{
Amtul Qayoom ${ }^{a *}$, Syed Arif Kazmi ${ }^{\mathrm{b}}$ and Saeeda Nadir Ali ${ }^{\mathrm{a}}$ \\ ${ }^{a}$ Department of Chemistry, NED University of Engineering and Technology, \\ Karachi-75270, Pakistan \\ ${ }^{b}$ H.E.J. Research Institute of Chemistry, International Center for Chemical and Biological Sciences (ICCBS), \\ University of Karachi, Karachi- 75270, Pakistan
}

(received March 21, 2016; revised September 10, 2016; accepted September 19, 2016)

\begin{abstract}
The present study was conducted to investigate surface properties of turmeric in order to evaluate its detoxification potential and ability to sequester toxic metals ions. Scanning Electron Microscopy (SEM), Energy Dispersion Spectroscopy (EDS), Infra-Red (IR) spectroscopy and potentiometric titrations were employed for characterisation of the surface of turmeric powder. Spectroscopic studies revealed that the surface of turmeric powder was porous mainly composed of polymeric $-\mathrm{OH},-\mathrm{NH},-\mathrm{CH}_{2},-\mathrm{COO}$ and $-\mathrm{OH}$ groups of polysaccharides. From potentiometric titrations and modelling of batch titration data, it was found that surface of the turmeric contains at least four binding sites with $\mathrm{pKa}$ values $3.56\left(\mathrm{pK}_{1}\right), 4.83$ $\left(\mathrm{pK}_{2}\right), 7.68\left(\mathrm{pK}_{3}\right)$ and $10.4\left(\mathrm{pK}_{4}\right)$. Turmeric powder contains highest concentration of amino and hydroxyl groups for the $\mathrm{pK}_{4}$ values i.e., $0.55 \mathrm{mmol} / \mathrm{g}$. The total binding sites concentration for turmeric powder was $1.2 \mathrm{mmol} / \mathrm{g}$.
\end{abstract}

Keywords: turmeric, chelation, surface characterisation, potentiometric titration

\section{Introduction}

Rapid increase in industrialisation, population growth and urbanisation has largely contributed to abundance of heavy metals in drinking water, air and soil. In many developing countries, agricultural land is often irrigated with raw sewage (Farrag et al., 2016; Meng et al., 2016; Yousaf et al., 2016). Industrial and domestic sewage is also disposed of into fresh water systems to be used to irrigate agricultural land. In Pakistan, untreated sewage and industrial water is commonly used for the cultivation of vegetables around the urban areas of Pakistan (Shakir et al., 2017; Khan et al., 2016; Uzma et al., 2016). Thus, food is one of the key sources of toxic metals intake by human beings.

The practice of using certain plants or their parts as natural chelates for detoxification of living organisms is quite topical. Scientists from USA, India, Pakistan, China, France and others explored the properties of local food and plants for detoxification. Such are the cumin, turmeric, garlic, tea and others (Chang et al., 2012; El-Ashmawy et al., 2006; Wong and Kitts, 2006 by Komy, 2004). There are several herbs that are considered useful in the elimination of heavy metals. Inclusion of high sulphur foods such as asparagus, onions, garlic, legumes and eggs in diet assist the body *Author for correspondence; E-mail: amtulq@gmail.com in preventing uptake and retention of many toxic metals. Apples pectin binds most toxic metals and removes them from the body (Kartel et al., 1999).

Plant derived materials consisting largely of polysaccharides, proteins and lipids have a broad range of functional groups, which can sequester metal ions e.g., hydroxyl, carboxylate, amino and sulphate groups etc. (Lesmana et al., 2009; Choi and Yun, 2006). Besides these functional groups, polysaccharides also exhibit ion exchange affinities (Nasernejad et al., 2005; Zouboulis et al., 1999; Sag and Veglio et al., 1997; Kutsal, 1996). Diversity of functional groups on their surface makes them act as natural chelates and their binding properties may be associated with their chemical heterogeneity.

Turmeric is widely used as a spice, colouring agent, preservative, cosmetic and as medicinal herb in traditional medicine systems (Unani, Ayurveda, Sidha and Tibetan) as studied by Remadevi and Ravindran (2007) and Eigner and Scholz (1999). The primary colouring pigment of turmeric i.e., curcumin is used as a food colour in spices, cheese, mustard, potato flakes, cereals, pickles, soups, yogurt, ice creams, etc., in Asiatic and Western cuisines. Studies have indicated that turmeric is non-toxic to humans even upon taking 8000 $\mathrm{mg} /$ day taken continuously (Cheng et at., 2001). 
Because of the presence of curcuminoids, proteins and carbohydrates, turmeric powder provides a variety of binding sites for metal ions and acts as a natural chelate (Qayoom and Kazmi, 2012; Qayoom Amtul et al., 2009). The attraction depends on the surface constitution, type and number of ligand groups and their affinity for particular metals. The physical and chemical characteristic of turmeric is important to interpret interaction between turmeric surface and metal ions. Recently various studies have been conducted to investigate isolation and characterisation of turmeric constituents and their therapeutic potential and its role as detoxifying agent but no studies have been conducted to explore relationship between surface properties of turmeric and its detoxifying abilities (El-Barbary, 2016; Harsha et al., 2016; Sun et al., 2016) . Present research work was aimed to investigate surface properties of turmeric powder in order to evaluate its potential as a natural chelate for $\mathrm{Cu}(\mathrm{II})$ and $\mathrm{Cd}(\mathrm{II})$ from their aqueous solutions. SEM-EDS and IR analysis were carried out to study changes in morphology and identification of functional groups involved in $\mathrm{Cu}$ (II) and $\mathrm{Cd}(\mathrm{II})$ binding onto turmeric powder surface. Potentiometric titration data of turmeric suspensions was modelled using modelling programme ProtoFit to determine surface dissociation constants and metal binding site concentration.

\section{Materials and Methods}

Adsorbate stock solutions of copper(II) and cadmium(II) were prepared by dissolving $0.617 \mathrm{~g} \mathrm{Cd}\left(\mathrm{NO}_{3}\right)_{2} \cdot 4 \mathrm{H}_{2} \mathrm{O}$ and $0.50 \mathrm{~g} \mathrm{CuSO}_{4} .5 \mathrm{H}_{2} \mathrm{O}$ per liter of deionised water. Dilute solutions of different working concentrations of $\mathrm{Cu}$ (II) and $\mathrm{Cd}(\mathrm{II})$ were prepared from their stock solutions. Adsorption experiments were conducted as follows: Accurately weighed turmeric powder $(0.500$ $\pm 0.001 \mathrm{~g}$ ) was added to the $50.0 \mathrm{~mL}$ metal solution to obtain suspension. The suspension was adjusted to $\mathrm{pH}$ 6 for $\mathrm{Cu}$ (II) and $\mathrm{pH} 7$ for $\mathrm{Cd}(\mathrm{II})$ by adding required volume of $0.1 \mathrm{M} \mathrm{HNO}_{3}$ and $\mathrm{NaOH}$ solutions. Both suspensions were stirred at a constant speed at temperatures $310 \mathrm{~K}$ for $60 \mathrm{~min}$. The contents were then suction filtered through filter paper, Whatman no. 1 and air dried overnight at room temperature.

SEM-EDS Studies. The morphology of the turmeric powder before and after $\mathrm{Cu}$ (II) and $\mathrm{Cd}$ (II) binding was investigated by using Scanning Electron Microscope (JSM5910, JEOL, Japan) EDS detector (INCA200/ Oxford Instruments, UK). EDS analysis was employed to confirm the identification of metal ions present on sample surface.

IR studies. Turmeric powder samples prior and after treating with $\mathrm{Cu}$ (II) and $\mathrm{Cd}(\mathrm{II})$ solution were dried overnight at room temperature to avoid any moisture retained which could interfere with analysis of hydroxyl groups on the surface. The samples were ground and mixed well with $\mathrm{KBr}$ and then compressed in the disc. The discs were scanned through a wavelength range from 500 to $4000 \mathrm{~cm}^{-1}$ into transmission mode using IR spectrometer (Bruker Vector 22 19300). IR spectra of control, $\mathrm{Cu}$ (II) and $\mathrm{Cd}(\mathrm{II})$ treated turmeric powder were recorded.

Potentiometric studies. Turmeric powder suspension was prepared having solid-to-liquid ratio of $10 \mathrm{~g} / \mathrm{L}$ in inert electrolyte concentrations of $0.1 \mathrm{M} \mathrm{NaNO}_{3}$. The suspension was stirred for one hour to reach the equilibrium. The potentiometric titration was conducted by adding a known concentration of $\mathrm{HCl}$ to turmeric powder suspension to decrease the initial $\mathrm{pH}$ and then titrating with standardized solutions of $\mathrm{NaOH}$. The $\mathrm{pH}$ of the suspension solution was recorded after each titrant addition by $\mathrm{pH}$-meter calibrated with $\mathrm{pH} 4$ and $\mathrm{pH} 7$ buffers. Each sample was also conducted in blank. Triplicate measurements were made to ensure the reproducibility.

Experimental data obtained from potentiometric titration of turmeric powder suspension were normalized as surface charge $(\mathrm{QH}, \mathrm{mmol} / \mathrm{g})$ concentration versus suspension $\mathrm{pH}$.

$\mathrm{Q}_{\mathrm{H}}$ values were calculated according to the following charge balance equation (Pagnanelli et al., 2005).

$$
\mathrm{Q}_{\mathrm{H}}=\sum_{\mathrm{j}=1}^{\mathrm{n}}\left[\mathrm{s}_{\mathrm{j}}^{-}\right]=\frac{\left(\mathrm{C}_{\mathrm{B}^{-}} \mathrm{C}_{\mathrm{A}}+\left[\mathrm{H}^{+}\right]-\left[\mathrm{OH}^{-}\right]\right) \mathrm{V}}{\mathrm{m}}
$$

where:

$\mathrm{S}_{\mathrm{j}}(\mathrm{mmol} / \mathrm{g})=$ concentration of dissociated form of generic $S_{j}$ sites in turmeric; $C_{B}(\mathrm{mmol} / \mathrm{L})$ and $C A$ $(\mathrm{mmol} / \mathrm{L})=$ the base and acid concentrations, respectively after each addition; $\mathrm{V}(\mathrm{L})=$ the total suspension volume after each addition of titrant; $\mathrm{H}^{+}$ $(\mathrm{mmol} / \mathrm{L})=$ protons concentration in the solution obtained by potentiometric measurements; $\mathrm{OH}^{-}$ $(\mathrm{mmol} / \mathrm{L})$ is estimated by taking into account water dissociation constant and $\mathrm{m}(\mathrm{g})=$ amount of turmeric powder. ProtoFit is modelling software designed to calculate surface protonation constants and concentration of binding sites from titration data. 
Computational methods. Logger Pro 3.8.2 software was used to record the titration data on Pentium IV computer. This data allowed the qualitative and quantitative determination of acidic sites of turmeric surface. The modeling program ProtoFit version 2.0 was employed to fit the titration data to theoretical nonelectrostatic proton binding model curve. Potentiometric titration data was used to estimate types of functional groups responsible for the observed buffering capacities, their associated proton binding constants as well as their concentrations on turmeric surface.

Surface protonation model (Background). A given surface may contain a number of functional groups, each with its own site concentration. These binding sites present on surfaces are capable of accepting or releasing proton from/to the solution. These binding sites could be acidic, basic or amphoteric depending upon protonation/deprotonation reactions taking place. Acidic sites are those that change from neutral to negatively charged with increasing $\mathrm{pH}$ and basic sites take on positive charge with decreasing $\mathrm{pH}$ and are neutral at higher $\mathrm{pH}$ conditions (Pan et al., 2007)

$$
\begin{aligned}
& \equiv \mathrm{SH}^{\mathrm{o}} \rightleftarrows \equiv \mathrm{S}^{-}+\mathrm{H}^{+} \\
& \equiv \mathrm{SH}_{2}^{+} \rightleftarrows \equiv \mathrm{SH}^{\mathrm{o}}+\mathrm{H}^{+}
\end{aligned}
$$

where:

$\equiv \mathrm{S}$ represents binding site present on the surface; in Eq. (2) $\equiv \mathrm{SH}^{\mathrm{o}}$ exhibits acidic behaviour, releasing a proton and in Eq. (3) $\equiv \mathrm{SH}^{\circ}$ acts as a basic site and absorbs proton. If a surface is capable of exhibiting both behaviours, it is amphoteric. The equilibrium mass action for Eq. (2) and (3) are:

$$
\begin{aligned}
& \frac{\left\{\equiv \mathrm{S}^{-}\right\} \mathrm{a}_{\mathrm{H}^{+}}}{\left\{\equiv \mathrm{SH}^{\circ}\right\}}=\mathrm{K}_{1} \exp \frac{(\mathrm{F} \Psi)}{\mathrm{RT}} \\
& \frac{\left\{\equiv \mathrm{SH}^{\circ}\right\} \mathrm{a}_{\mathrm{H}^{+}}}{\left\{\equiv \mathrm{SH}_{2}^{+}\right\}}=\mathrm{K}_{2} \exp \frac{(\mathrm{F} \Psi)}{\mathrm{RT}}
\end{aligned}
$$

constrained by mass balance expression

$$
\{\equiv \mathrm{SH}\}_{\text {total }}=\left\{\equiv \mathrm{SH}^{\mathrm{o}}\right\}+\left\{\equiv \mathrm{S}^{-}\right\}+\left\{\equiv \mathrm{SH}_{2}^{+}\right\}
$$

where:

\{\} denotes the concentrations in $\mathrm{mol} / \mathrm{L}$ of solution, $\mathrm{a}_{\mathrm{H}^{+}}$refers to the thermodynamic activity of $\mathrm{H}^{+}, \mathrm{F}$ represents Faraday's constant, $\mathrm{K}_{1}$ and $\mathrm{K}_{2}$ are equilibrium constants, and $\mathrm{T}$ is absolute temperature (Van Cappellen et al., 1993). The surface potential, $\Psi$ is a function of surface charge, $\sigma$. The aim of surface protonation constants determination is to determine values of $\mathrm{K}_{1}$ and/or $\mathrm{K}_{2}$ and $\{\equiv \mathrm{SH}\}_{\text {total }}$ for each discrete surface site as required by the given model.

Determination of the buffer value. Following proton mass balance equation is the basis for the ProtoFit approach for a system with zero solution alkalinity. (Turner and Fein, 2006).

$$
\Delta \mathrm{n}_{\mathrm{H}^{+}, \text {total, } \mathrm{i}}=\Delta \mathrm{n}_{\mathrm{H}^{+}},{ }_{\text {water, } \mathrm{i}}+\Delta \mathrm{n}_{\mathrm{H}^{+}, \text {ads }, \mathrm{i}}
$$

where:

$\Delta \mathrm{n}_{\mathrm{H}^{+}}$is the mole of protons added to the system as a whole (total), water and turmeric surface from the start to step. Surface proton buffering function $\left(\mathrm{Q}^{*}\right.$ ads $)$ is the measure of $\mathrm{pH}$ dependency of the ability of surface to buffer solution $\mathrm{pH}$ and can be calculated using $\Delta \mathrm{n}_{\mathrm{H}^{+}}$total, $\mathrm{i}$ as follows:

$$
\mathrm{Q}_{\mathrm{ads}}=\frac{\Delta \mathrm{n}_{\mathrm{H}^{+}},{ }_{\mathrm{ads}, \mathrm{i}}}{\mathrm{S}}
$$

where:

$\mathrm{S}$ is the mass of turmeric powder.

$$
\mathrm{Q}_{\mathrm{ads}}^{*}=\frac{\mathrm{dQ}_{\mathrm{ads}}}{\mathrm{dpH}}
$$

In order to optimize model constants ProtoFit minimizes weighed sum of square difference i.e., SS* between $\left(\mathrm{Q}^{*}\right.$ ads) and ( $\mathrm{F}_{\text {ads }}^{*}$ (model proton buffering function). The optimization continues to adjust the model constants until the value of $\mathrm{SS}^{*}$ reaches at a minimum.

\section{Results and Discussion}

SEM-EDS. Scanning electron micrographs of unloaded, $\mathrm{Cu}$ (II) loaded and $\mathrm{Cd}$ (II) loaded turmeric powder are shown in Fig. 1. It can be observed that turmeric powder has significant numbers of pores, where metal ions can be trapped and adsorbed. A distinct change in surface morphology of turmeric powder was observed after binding of copper and cadmium. The peaks of carbon, nitrogen and oxygen were recorded in EDS spectra showing the presence of these elements in the turmeric powder as main constituents. EDS spectra of copper (II) and cadmium (II) adsorbed turmeric showed the peaks of copper and cadmium in addition to those recorded in the turmeric powder. 
IR Studies. IR study was carried out to determine functional groups involved in $\mathrm{Cu}$ (II) and $\mathrm{Cd}$ (II) binding onto turmeric powder surface. The IR spectra of control, $\mathrm{Cu}$ (II) and $\mathrm{Cd}$ (II) treated turmeric are shown in Fig. 2-4, respectively and salient peaks of control and metal loaded turmeric powder samples are compared in Table 1.

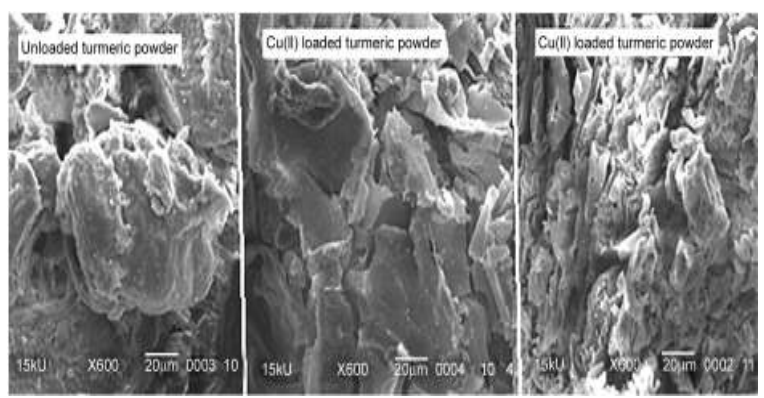

Fig 1. Scanning electron micrographs of unloaded, $\mathrm{Cu}(\mathrm{II})$ and $\mathrm{Cd}(\mathrm{II})$ loaded turmeric powder.

IR spectra showed that surface of turmeric powder is primarily comprised of polymeric $\mathrm{OH}, \mathrm{NH}, \mathrm{CH}_{2}$ and $\mathrm{COO}$ groups, and $\mathrm{OH}$ groups. Hydroxyl groups originate basically from polysaccharides; carboxyl groups can be associated with proteins whereas amino groups are mostly present in proteins. All these groups have been known for their affinity for heavy metal chelation (Anayurt et al., 2009; Al-Degs et al., 2006).

The IR spectra of metal treated turmeric powder showed slight changes in the absorption peak frequencies. The

Table 1. Comparison of Infrared band in the region of $3500-500 \mathrm{~cm}^{-1}$

\begin{tabular}{|c|c|c|c|}
\hline Functional groups & $\begin{array}{l}\text { unloaded } \\
\text { turmeric } \\
\text { powder }\end{array}$ & $\begin{array}{l}\text { Cd-loaded } \\
\text { turmeric } \\
\text { powder }\end{array}$ & $\begin{array}{l}\text { Cu-loaded } \\
\text { turmeric } \\
\text { powder }\end{array}$ \\
\hline & & $\mathrm{cm}^{-1}$ & \\
\hline $\mathrm{O}-\mathrm{H}$ and $\mathrm{N}-\mathrm{H}$ stretching & 3408 & 3424 & 3419 \\
\hline -CH stretching & 2924.6 & 2925.6 & 2924.5 \\
\hline $\begin{array}{l}>\mathrm{C}=\mathrm{N}-,>\mathrm{C}=\mathrm{C}-, \mathrm{C}=\mathrm{O} \text { stretch } \\
\text { to } \mathrm{N}-\mathrm{H} \text { bending (cis form), } \\
-\mathrm{CH}_{2} \text { scissoring or }-\mathrm{CH}_{3} \text { anti }\end{array}$ & 1631.2 & 1631.3 & 1634.5 \\
\hline $\begin{array}{l}\text { symmetrical bending vibration } \\
\text { and } \mathrm{O}-\mathrm{H} \text { deformation }\end{array}$ & 1429.5 & 1432 & 1427 \\
\hline $\mathrm{C}(=\mathrm{O}) \mathrm{O}^{--}$symmetric stretching & 1375.7 & 1380.7 & 1383.2 \\
\hline \multicolumn{4}{|l|}{ The $(\mathrm{C}=\mathrm{O})-\mathrm{O}^{-}$stretching vibration, } \\
\hline$-\mathrm{OH}$ in-plane deformation & 1262.3 & 1274.4 & 1271.4 \\
\hline Stretching vibration of C-O-C & 1160.2 & 1162.1 & 1162.1 \\
\hline Stretching vibration of $\mathrm{OH}$ & 1031.5 & 1032.7 & 1031.0 \\
\hline
\end{tabular}

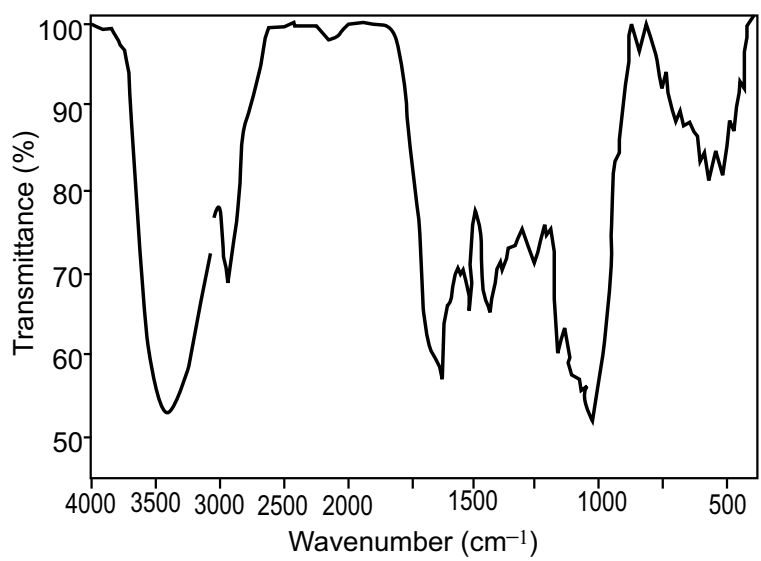

Fig. 2. IR spectra of unloaded turmeric powder.

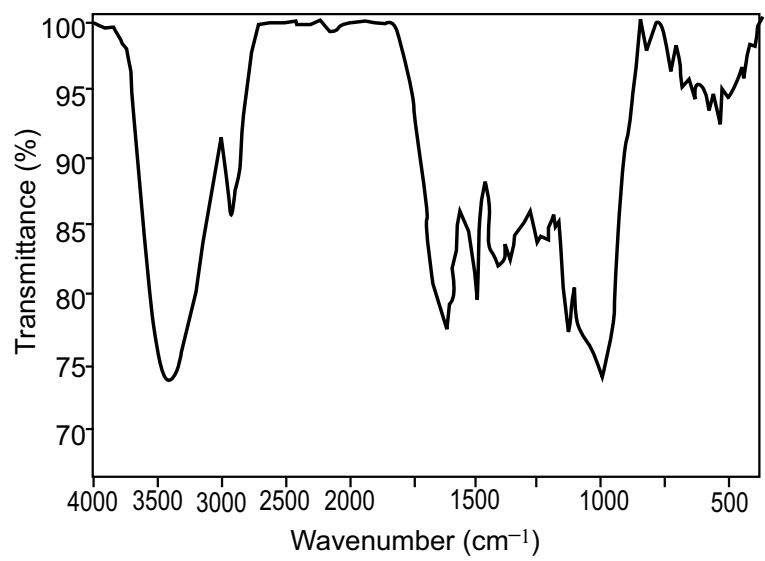

Fig. 3. IR Spectra of $\mathrm{Cu}(\mathrm{II})$ loaded turmeric powder.

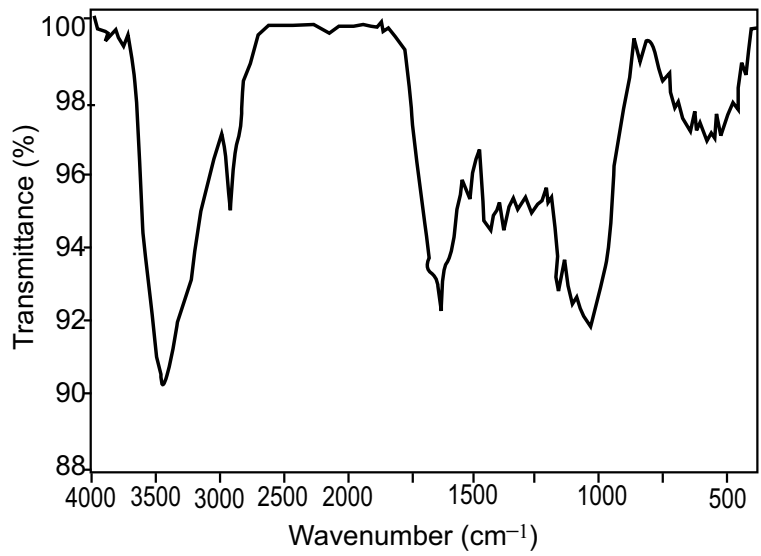

Fig. 4 IR Spectra of Cd(II) loaded turmeric powder

absorbance of most of the peaks in $\mathrm{Cu}$ (II) and $\mathrm{Cd}(\mathrm{II})$ treated turmeric powder is slightly shifted to higher frequencies. This shift in the absorbance indicated that surface of the turmeric powder was capable of interacting 
and binding metal ions. Changes in the spectra of loaded turmeric powder are attributed to the interaction of $\mathrm{Cu}$ (II) and $\mathrm{Cd}(\mathrm{II})$ with the hydroxyl, carboxyl and amino groups on the turmeric surface. The broadness of the $\mathrm{O}-\mathrm{H}$ and $\mathrm{N}-\mathrm{H}$ stretching band decreased in spectra of $\mathrm{Cu}$ (II) and $\mathrm{Cd}$ (II) loaded turmeric powder. This may be due to decrease in $\mathrm{H}-\mathrm{O}-\mathrm{H}$ interaction. No change was observed in the frequency of $\mathrm{C}-\mathrm{H}$ group after treating with $\mathrm{Cu}(\mathrm{II})$ and $\mathrm{Cd}(\mathrm{II})$ ions. This showed that $\mathrm{C}-\mathrm{H}$ group is not involved in the binding of $\mathrm{Cu}(\mathrm{II})$ and Cd(II) ions.

Potentiometric titration. A typical titration curve exhibiting that turmeric powder provides considerable buffering capacity over a wide $\mathrm{pH}$ range is presented in Fig. 5. This observed buffering is due to the protonation and deprotonation of functional groups present on the surface of the turmeric powder.

Point of Zero Charge (PZC) is defined as the $\mathrm{pH}$ value at which surface charge becomes equal to zero i.e., electrically neutral surface.

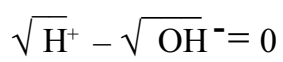

The value of PZC obtained from the $\mathrm{x}$-intercept of $\mathrm{Q}_{\mathrm{H}}$ versus pH plot (Fig. 6) was found to be 8.1. Thus at $\mathrm{pH}>8.1$ turmeric powder surface became increasingly negatively charged and at $\mathrm{pH}$ below 8.1 , the surface became increasingly positive charged. The existence of PZC indicated that the turmeric suspension developed a net positive charge at low $\mathrm{pH}$ values, indicating the presence of at least one positively ionizing, plausibly amino group. Those surfaces which only contain negatively ionizing groups such as carboxyl, hydroxyl and phosphoryl groups could not develop a net positive charge at low $\mathrm{pH}$. Active sites in the acidic $\mathrm{pH}$ range are usually carboxyl groups whereas active sites in the basic $\mathrm{pH}$ range are chiefly amine and phenolic groups.

Modeling results. The results obtained after ProtoFit optimizations are summarized in Table 2. Weighed

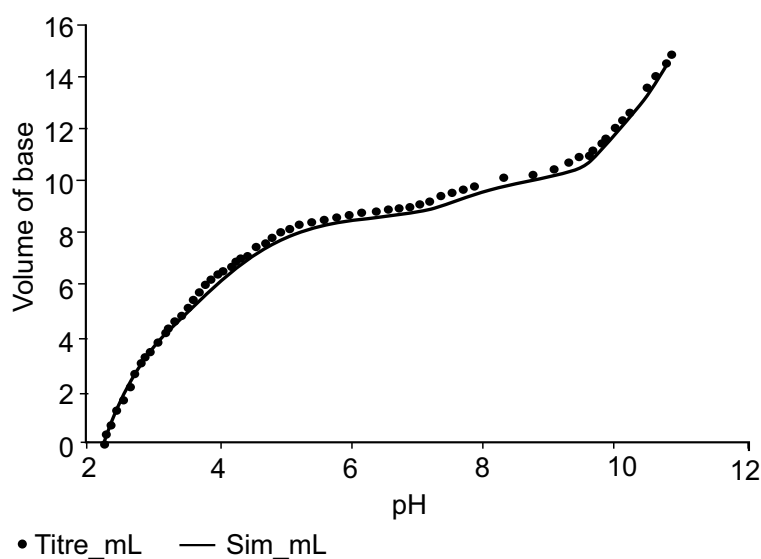

Fig. 5. Raw titration data compared with model simulation for $1 \mathrm{~g} / 100 \mathrm{~mL}$ suspension of turmeric powder in inert electrolyte concentrations of $0.1 \mathrm{M} \mathrm{NaNO}_{3}$.

sum of squares value, $S S^{*}$ (smaller values reflect better fits), represents the goodness of the fit. ProtoFit continues to adjust the values of model constants until the value of $S S^{*}$ reaches at a minimum. The best fit was achieved by using a non-electrostatic four acidic sites model in ProtoFit (Fig. 7). Hence, four different acidity constants

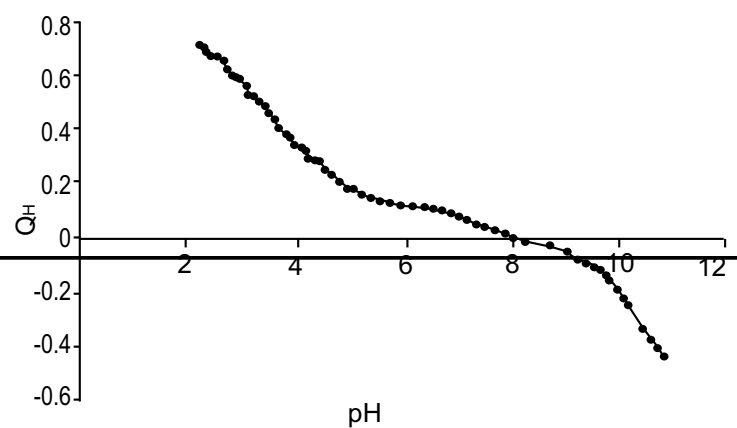

Fig. 6. Surface charge $\left(\mathrm{Q}_{\mathrm{H}}, \mathrm{mmol} / \mathrm{g}\right)$ versus $\mathrm{pH}$ of $1 \mathrm{~g} / 100 \mathrm{~mL}$ turmeric powder suspension in inert electrolyte concentrations of $0.1 \mathrm{M}$ $\mathrm{NaNO}_{3}$.

Table. 2. Acidity constants and binding site concentrations ( $\mathrm{mmol} / \mathrm{g}$ ) calculated by Protofit using the four site non-electrostatic model

\begin{tabular}{|c|c|c|c|c|c|c|c|c|c|}
\hline $\mathrm{pK}_{1}$ & $\mathrm{C}_{1}$ & $\mathrm{pK}_{2}$ & $\mathrm{C}_{2}$ & $\mathrm{pK}_{3}$ & $\mathrm{C}_{3}$ & $\mathrm{pK}_{4}$ & $\mathrm{C}_{4}$ & $\mathrm{C}_{\text {total }}$ & $\mathrm{S} \mathrm{S}^{*}$ \\
\hline 3.56 & 0.35 & 4.83 & 0.16 & 7.68 & 0.15 & 10.4 & 0.55 & 1.2 & 7.23 \\
\hline \multicolumn{2}{|c|}{$29.16 \%$} & \multicolumn{2}{|c|}{$13.33 \%$} & \multicolumn{2}{|c|}{$12.5 \%$} & \multicolumn{2}{|c|}{$45.88 \%$} & & \\
\hline \multicolumn{2}{|c|}{ Strong carboxyl groups } & \multicolumn{2}{|c|}{ Weak carboxyl groups } & \multicolumn{2}{|c|}{ Very weak phenolic groups } & \multicolumn{2}{|c|}{ Amines /hydroxyl } & & \\
\hline
\end{tabular}


were obtained: $3.56\left(\mathrm{pK}_{1}\right), 4.83\left(\mathrm{pK}_{2}\right), 7.68\left(\mathrm{pK}_{3}\right)$ and $10.4\left(\mathrm{pK}_{4}\right) \cdot \mathrm{pK}_{1}$ can be associated to strong carboxyl group attached to aromatic structures. $\mathrm{pK}_{2}$ can be due to weak carboxyl group associated with aliphatic chains. $\mathrm{pK}_{3}$ can be attributed to very weak phenolic groups and $\mathrm{pK}_{4}$ can be ascribed to amino and/or hydroxyl group, respectively (Merdy et al., 2009; Reddad et al., 2002). Turmeric powder has highest concentration of amino and hydroxyl groups for the estimated $\mathrm{pK}_{4}$ values i.e., $0.55 \mathrm{mmol} / \mathrm{g}$. The main parameter concerns the total

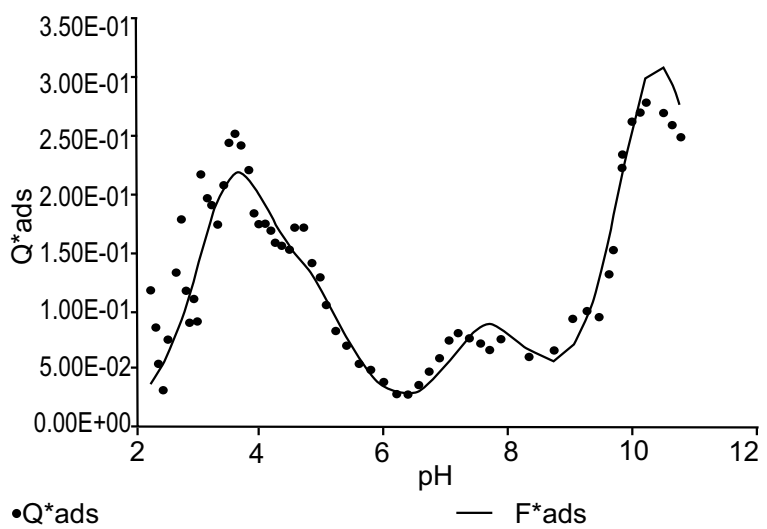

Fig. 7. $\mathrm{Q}^{*}$ ads function compared with model predictions for $1 \mathrm{~g} / 100 \mathrm{~mL}$ suspension of turmeric powder in inert electrolyte concentrations of $0.1 \mathrm{M} \mathrm{NaNO}$.

binding site concentration (or buffering capacity). The total site concentration for turmeric powder was 1.2 $\mathrm{mmol} / \mathrm{g}$.

It was found that the chelation of $\mathrm{Cu}$ (II) and $\mathrm{Cd}$ (II) strongly depends upon $\mathrm{pH}$ of the solution and surface speciation of the turmeric powder. At low $\mathrm{pH}$ values, functional groups present on the turmeric surface are fully protonated and metal ion chelation is negligible. On increasing $\mathrm{pH}$, the functional groups gradually deprotonate, forming negatively charged metal binding sites which result in increasing $\mathrm{Cu}$ (II) and $\mathrm{Cd}(\mathrm{II})$ chelation.

\section{Conclusion}

In the present study, surface properties of turmeric powder were examined by spectroscopic techniques and potentiometric titrations. Spectroscopic studies revealed that the surface of turmeric powder was porous mainly composed of polymeric - $\mathrm{OH},-\mathrm{NH},-\mathrm{CH}_{2},-\mathrm{COO}$ and $-\mathrm{OH}$ groups of polysaccharides. It was found that surface of the turmeric contains at least four binding sites i.e., strong carboxyl group attached to aromatic structures, weak carboxyl group associated with aliphatic chains, very weak phenolic groups and amino and/or hydroxyl group, respectively. Turmeric powder contains highest concentration of amino and hydroxyl groups. Presence of these binding sites on turmeric surface makes it appropriate chelating agent for ingested toxic metals.

\section{References}

Al-Degs, Y. S., El-Barghouthi, M. I., Issa, A. A., Khraisheh, M. A., Walker, G. M. 2006. Sorption of $\mathrm{Zn}$ (II), $\mathrm{Pb}$ (II), and $\mathrm{Co}(\mathrm{II})$ using natural sorbents: equilibrium and kinetic studies. Water Research, 40: $2645-2658$.

Anayurt, R.A., Sari, A., Tuzen, M. 2009. Equilibrium, thermodynamic and kinetic studies on biosorption of $\mathrm{Pb}$ (II) and $\mathrm{Cd}$ (II) from aqueous solution by macrofungus (Lactarius scrobiculatus) biomass. Chemical Engineering Journal, 151: 255-261.

Chang, M. S., Park, M. J., Jeong, M. C., Kim, D. M., Kim, G. H. 2012. Antioxidative activities and antibrowning effects of green tea extracts and propolis. Korean Journal of Food and Cookery Science, 28: 319-326.

Cheng, A.L., Hsu, C.H., Lin, J.K., Hsu, M.M., Ho, Y.F., Shen, T.S., Ko, J.Y., Lin, J.T., Lin, B.R., MingShiang, W., Yu, H.S., Jee, S. H., Chen, G. S., Chen, T.M., Chen, C. A., Lai, M.K., Pu, Y.S., Pan, M.H., Wang, Y.J., Tsai, C.C., Hsieh, C.Y. 2001. Phase I clinical trial of curcumin, a chemopreventive agent, in patients with high-risk or pre-malignant lesions. Anticancer Research, 21: 2895-2900.

Choi, S.B., Yun, Y.-S. 2006. Biosorption of cadmium by various types of dried sludge: an equilibrium study and investigation of mechanisms. Journal of Hazardous Materials, 138: 378-383.

Eigner, D., Scholz, D. 1999. Ferula asafoetida and Curcuma longa in traditional medical treatment and diet in Nepal. Journal of Ethnopharmacology, 67: 1-6.

El-Ashmawy, I.M., Ashry, K. M., El-Nahas, A. F., Salama, O. M. 2006. Protection by turmeric and myrrh against liver oxidative damage and genotoxicity induced by lead acetate in mice. Basic Clinical Pharmacology \& Toxicology, 98: 32-37.

El-Barbary, M.I. 2016. Detoxification and antioxidant 
effects of garlic and curcumin in Oreochromis niloticus injected with aflatoxin $\mathrm{B}_{1}$ with reference to gene expression of glutathione peroxidase (GPx) by RT-PCR. Fish Physiology and Biochemistry, 42: 617-629.

Farrag, K., El Bastamy, E.S., Ramadan, A. 2016. Health risk assessment of heavy metals in irrigated agricultural crops, El-Saff wastewater canal, Egypt. CLEAN - Soil, Air, Water, 44: 1-10.

Harsha, M.R., Chandra Prakash, S. V., Dharmesh, S.M. 2016. Modified pectic polysaccharide from turmeric (Curcuma longa): A potent dietary component against gastric ulcer. Carbohydrate Polymers, 138: 143-155.

Kartel, M.T., Kupchik, L.A., Veisov, B.K. 1999. Evaluation of pectin binding of heavy metal ions in aqueous solutions. Chemosphere, 38: 2591-2596.

Khan, Z.I., Ahmad, K., Ashraf, M., Parveen, R., Bibi, Z., Mustafa, I., Noorka, I.R., Tahir, H.M., Akram, N.A., Ullah, M.F., Yaqoob, R. 2016. Risk assessment of heavy metal and metalloid toxicity through a contaminated vegetable (Cucurbita maxima) from wastewater irrigated area: A case study for a site-specific risk assessment in Jhang, Pakistan. Human and Ecological Risk Assessment: An International Journal, 22: 86-98.

Komy, Z.R. 2004. Determination of acidic sites and binding toxic metal ions on cumin surface using nonideal competitive adsorption model. Journal of Colloid and Interface Science, 270: 281-287.

Lesmana, S. O., Febriana, N., Soetaredjo, F. E., Sunarso, J., Ismadji, S. 2009. Studies on potential applications of biomass for the separation of heavy metals from water and wastewater. Biochemical Engineering Journal, 44: 19-41.

Meng, W., Wang, Z., Hu, B., Wang, Z., Li, H., Goodman, R.C. 2016. Heavy metals in soil and plants after long-term sewage irrigation at Tianjin China: A case study assessment. Agricultural Water Management, 171: 153-161.

Merdy, P., Gharbi, L.T., Lucas, Y. 2009. Pb, $\mathrm{Cu}$ and $\mathrm{Cr}$ interactions with soil: Sorption experiments and modelling. Colloids and Surfaces A: Physicochemical and Engineering Aspects, 347: 192-199.

Nasernejad, B., Zadeh, T. E., Pour, B. B., Bygi, M. E., Zamani, A. 2005. Camparison for biosorption modeling of heavy metals ( $\mathrm{Cr}(\mathrm{III}), \mathrm{Cu}(\mathrm{II}), \mathrm{Zn}$ (II)) adsorption from wastewater by carrot residues. Process Biochemistry, 40: 1319-1322.

Pagnanelli, F., Mainelli, S., De Angelis, S., Toro, L.
2005. Biosorption of protons and heavy metals onto olive pomace: Modelling of competition effects. Water Research, 39:1639-1651.

Pan, J., Liu, R., Tang, H. 2007. Surface reaction of Bacillus cereus biomass and its biosorption for lead and copper ions. Journal of Environmental Sciences (China), 19: 403-408.

Premavali, S. 2007. Turmeric as a spice and colorant. In: Turmeric: The Genus Curcuma. P. N. Ravindran, K. N. Babu, and K. Sivaraman (eds.), pp. 437-450, $1^{\text {st }}$ edition, CRC Press, USA.

Qayoom, A., Kazmi, S.A. 2012. Effect of temperature on equilibrium and thermodynamic parameters of $\mathrm{Cu}(\mathrm{II})$ adsorption onto turmeric powder. Journal of Chemical Society of Pakistan, 34: 1084-1090.

Qayoom, A., Kazmi, S.A., Naushaba, R. 2009. Removal of $\mathrm{Cu}$ (II) ions from aqueous solutions by turmeric powder. Journal of Chemical Society of Pakistan, 31: $876-881$.

Reddad, Z., Gerente, C., Andres, Y., Le Cloirec, P. 2002. Modeling of single and competitive metal adsorption onto a natural polysaccharide. Environmental Science \& Technology, 36: 2242-2248.

Remadevi, R., Ravindran, P. N. 2007. Turmeric in traditional medicine, In: Turmeric: The Genus Curcuma. P. N. Ravindran, K. N. Babu and K. Sivaraman (eds.), pp. 409-436, 1st edition, CRC Press, USA.

Sag, Y., Kutsal, T. 1996. The selective biosorption of chromium(VI) and copper(II) ions from binary metal mixtures by $R$. arrhizus. Process Biochemistry, 31: 561-572.

Shakir, S.K., Azizullah, A., Murad, W., Daud, M.K., Nabeela, F., Rahman, H., ur Rehman, S., Häder, D.P. 2017. Toxic metal pollution in Pakistan and its possible risks to public health. Reviews of Environmental Contamination and Toxicology, 242: 1-60

Sun, W., Wang, S., Zhao, W., Wu, C., Guo, S., Hongwei, G., Hongxun, T., Lu, J.J., Wang, Y., Chen, X.P. 2016. Chemical constituents and biological research on plants in the genus Curcuma. Critical Reviews in Food Science and Nutrition, DOI: 10 1080/ 10408398. 20161176554

Turner, B.F., Fien, J.B. 2006. ProtoFit: A program for determining surface promotion constants from titration data. Computers and Geosciences, 32: 1344-1356.

Uzma, S., Azizullah, A., Bibi, R., Nabeela, F., Muhammad, U., Ali, I., Rehman, Z.U., Häder, D.P. 
2016. Effects of industrial wastewater on growth and biomass production in commonly grown vegetables. Environmental Monitoring and Assessment, 188: 1-13.

Van Cappellen, P., Charlet, L., Stumm, W., Wersin, P. 1993. A surface complexation model of the carbonate mineral-aqueous solution interface. Geochimica et Cosmochimica Acta, 57: 3505-3518.

Veglio, F., Beolchini, F., Gasbarro, A. 1997. Biosorption of toxic metals: an equilibrium study using free cells of Arthrobacter sp. Process Biochemistry, 32: 99-105.

Wong, P.Y.Y., Kitts, D.D. 2006. Studies on the dual antioxidant and antibacterial properties of parsley (Petroselinum crispum) and cilantro (Coriandrum sativum) extracts. Food Chemistry, 97:505-515.

Yousaf, B., Amina, Liu, G., Wang, R., Imtiaz, M., Rizwan, M.S., Zia-ur-Rehman, M., Qadir, A., Si, Y. 2016. The importance of evaluating metal exposure and predicting human health risks in urban-periurban environments influenced by emerging industry. Chemosphere, 150: 79-89. Zouboulis, A. I., Rousou, E. G., Matis, K. A., Hancock, I. C. 1999. Removal of toxic metals from aqueous mixtures. Part 1: Biosorption. Journal of Chemical Technology \& Biotechnology, 74: 429-436. 